\title{
A HISTORY OF
}

\section{THE ROCK ISLAND DISTRICT CORPS OF ENGINEERS}

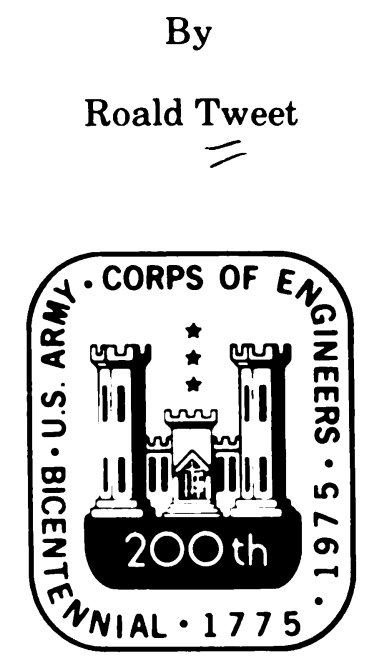

U. S. ARMY ENGINEER DISTRICT, ROCK ISLAND

ROCK ISLAND, ILLINOIS

UNIVERSITY OF MICHIGAN LIBRARIES JUNE 1975

JUL $9 \quad 1975$

For sale by the Superintendent of Documents, U. S. Government Printing Office, Washingt BEP.dSd 4502 BY THE 